\title{
PLOTS AND THAI CULTURAL CONTENTS FOR ASEAN TELEVISION DRAMA
}

\section{KANCHANA CHOKRIENSUKCHAI}

\author{
School of Communication Arts, the University of the Thai Chamber of Commerce, Thailand
}

\begin{abstract}
The purposes of this research were to study the exposure to television drama, the need of television drama plots and cultural contents in the television drama of ASEAN people. Also, to find out the patterns of exposure to television drama, the need of television drama plots and the need of cultural contents in the television drama of ASEAN people. The sample group was a group of 4,110 people and over from varied professions. The survey was conducted in 2017 using a questionnaire through the internet and local people. The result found that the exposure to television drama in ASEAN consists of 2 patterns: 1). The countries where the exposure to television drama is moderate to very high-level directions which include Thailand, Brunei, Philippines, Malaysia, Vietnam, Singapore, and Singapore. Indonesia and 2) the countries where the exposure to television drama is moderate to very low-level directions which include Cambodia and Laos. The pattern of exposure of plots of TV drama among people in ASEAN countries can be seen in 2 patterns: 1) countries with various plot exposure2) countries that have exposure to plots in a particular manner. Also, the pattern of the need of cultural contents in the television drama of ASEAN people can be seen in 2 patterns: 1) the need of cultural contents in the television drama of ASEAN in a variety of ways such as Thailand, Brunei, Philippines, Vietnam, and Indonesia. 2). the need of cultural contents in the television drama of ASEAN in a particular way such as Cambodia, Malaysia, Myanmar, Laos, and Singapore.
\end{abstract}

KEYWORDS: Thai Pattern Need Television Drama Asean

Received: Jul 10, 2017; Accepted: Aug 03, 2017; Published: Aug 11, 2017; Paper Id.: IJCMSAUG20172

\section{INTRODUCTION}

The AEC is the realization of the region's end goal of economic integration. It envisions ASEAN as a single market and production base, a highly competitive region, with equitable economic development, and fully integrated into the global economy. The AEC seeks to reduce or remove many trade barriers within the region with the goal to facilitate the free movement of goods, services, capital, and skilled labor within the group. It is an opportunity and challenge of the ASEAN member countries in trading within their bloc.

In marketing, a product is anything that can be offered to a market that might satisfy a want or need. In retailing, products are called merchandise. In manufacturing, products are bought as raw materials and sold as finished goods. Meanwhile, a service is another common product type. The nature of the good product is to be able to stimulate demand and to procreate demand for other products. Culture including Thai culture is recognized globally as the country product. The relationship between culture and economy has undergone an important shift in focus, from the mere conservation of culture to its economic enhancement, which reveals the links among culture, society, and economic development (Alberti and Giusti, 2012; Cooke and Lazzeretti, 2008; Lazzeretti, Capone, and Cinti 2011; Power and Scott, 2004, and Rabaneda, 2012). There are numerous benefits coming from the relationship between culture and others especially tourism since cultural resources are very often potential for 
attracting tourists. Cultural heritage makes cities distinctive and unique, and therefore different than others on the wide tourism market.

"Cultural tourism has become increasingly politicized as governments weigh up the advantages and disadvantages of this potentially lucrative industry, often viewing it as their sole economic option if they wish to compete in the global arena. The environmental and socio-cultural consequences of such decisions are often overlooked; hence it falls to the communities themselves to protect their own interests, usually with inadequate political support" (Smith, 2009:11).

From this point of view, one thing to keep in mind is the need to create cultural awareness for the target group of cultural trade. In other words, it is to make the culture a commodity for export. The culture of export products can be done in a variety of forms. Including, bringing culture into entertainment in the form of 'television dramas ', which are believed to be able to create both direct and indirect values, that is, in addition to being able to benefit directly in the form of money, it can also be used as an important communication tool to create other perceptions. The result can be seen in the case of the growth of Korean media markets bringing the wave to the Philippines'. The term Hallyu first mentioned in Chinese media and was used to refer to the popularity of Korean cultural products abroad, which include dramas and music. It also means — a sudden cold wave, a warning for the Chinese people to be cautious of Korean popular culture. (Jay-Ar M et.al: 2016)

Similarly, television dramas can serve as a channel to raise awareness about Thai culture in ASEAN countries where opportunities are available for Thai television dramas since more ASEAN people enjoy more television dramas from Asian countries. Television dramas can be used as a tool to influence the imitation behavior that is used to create economic value for Thailand. However, according to the television dramas, not all stories are successful in creating awareness. Television dramas creation has to meet the needs of the audience. Information needs of audience needs. Specifically, information related to television drama exposure, plots, cultural needs and commercial content of audiences in ASEAN countries. This study provides the basic information required for the production of television drama for ASEAN countries

\section{PURPOSES OF THE STUDY}

The purposes of this research were

- To study the exposure to television drama of ASEAN people.

- To study the need of television drama plots of ASEAN people.

- To study the need of cultural contents in the television drama of ASEAN people.

- To find out the patterns of exposure to television drama of ASEAN people.

- To find out the patterns of the need of television drama plots of ASEAN people.

- To find out the patterns of the need of cultural contents in the television drama of ASEAN people.

\section{RESEARCH METHODOLOGY}

As no other study has been previously conducted providing a foundation from which to draw an empirical analysis, this investigation was purely an exploratory exercise utilizing descriptive quantitative methods. The research investigation involved the survey instrument representative of Exposure to television drama, the need of television drama plots and the need of cultural contents in the television drama of ASEAN people. 


\section{Sample}

The sample group was a group of 4,110 people and over from varied professions. The survey was conducted in 2017 using a Cronbach's Alpha with each country was higher than 0.986 and the questionnaire was in English and ASEAN languages. The data was collected through the internet and local people.

\section{Data Analysis}

Descriptive statistics of frequencies, percentages, and means were generated for the survey data. An analysis was carried out to classify the countries, where pattern behavior is similar to cluster analysis and discriminant analysis. The results from an original smaller sample $(n=4,110)$ are not intended to be generalized to a larger population, but rather to provide a basis for further inquiry for testing hypotheses with larger samples in order to make generalizations.

\section{RESULTS}

The survey sample was composed of 1938 males (47.15\%) and 2,172 females (52.83\%). Of all the participants, 2,171 were in the age range 21-30 years (52.82\%), 2293 had the education level of bachelor's degree (55.79\%), 2524 were students $(61.41 \%)$. and 2,228 had revenues ranging from less than or equal to 36 US dollars, or 10,000 Baht (54.21\%).

\section{The Exposure to Television Drama of Asean People}

The results of the survey can be divided into countries as follows

\section{Cambodian}

Most Cambodians prefer to watch television series with 30 or 60 minutes long and broadcast 2-3 days/week. Prefer to watch simple understanding stories in the form of CD, DVD, BD and File. Most of them watch the foreign drama like Thai television dramas.

\section{Thai}

Most Thai people watch television series broadcast daily and have a long story line. Prefer to watch simple storyline and beautiful visual elements. Thai people commonly watch foreign television dramas, especially Korean dramas. Most people watch television series on many likes, read a synopsis and follow reviews on the Internet. Friends and Teasertrailer had the impact on decision making to watch television dramas.

\section{Brunei}

Most people in Brunei like watching Asian television dramas such as Korean and Chinese television series. Television dramas for Brunei must include well-portrayed and in each episode include the different story with broadcast content ends in 30 or 60 minutes. In addition, Brunei is more likely to refer to non-domestic television.

\section{Filipino}

Most Filipinos like to watch Korean Television dramas. Favorite Series Television Series is a multi-episode television series under the same storyline. In each episode should show the different story, such as investigative series with each episode has different cases and finished in 30 or 60 minutes. Most Filipinos watch television series on many likes, read a synopsis and follow reviews on the Internet. Friends and Teaser-trailer had the impact on most Filipinos decision making to watch television dramas. 


\section{Malaysian}

Most Malaysians watch only favorite series. Television Series should be a multi-episode television series under the same storyline. In each episode show different issues, content long for 30 or 60 minutes. Most Malaysians watch television series along with reading a synopsis and follow reviews on the Internet. Some groups are watching Television Series via CD, DVD, BD, and File. Malaysians pay more attention to the look and performance of actors. Friends and Teaser-trailer had the impact on decision making to watch television dramas.

\section{Myanmar}

Most Myanmar likes to watch Thai and Korean television drama. Most of them prefer to watch the drama that provides easy to understand and broadcast every day with the content finish in 30 or 60 minutes. Also, watching on television, and watch over CD, DVD, BD and File.

\section{Laos}

Most Lao people like watching Thai television. The content shown in Laos should be broadcasted 2-3 days/week and end in 30 or 60 minutes. Actors must be looking good and act naturally. Most Lao people are more likely to watch the series via television and CD, DVD, BD and files.

\section{Vietnamese}

Vietnamese watch Thai television series by watching only the series that is multi-episode series under the same storyline with each episode has a different case but the main character remains the same. They prefer daily long series of television shows. Most of them watch through CD, DVD, BD and File. Most Vietnamese also, watch foreign television shows alongside the original on YouTube.

\section{Singaporean}

Most Singaporean chooses to watch television dramas in a certain way. The television drama has aired in the episode with the duration of the broadcast is 30 or 60 minutes, 2-3 days/week. Most of them like watching a particular television series with easy-to-understand content and beautiful visual elements, fun, funny, show in English. Singaporeans are more open to foreign television dramas, especially Korean television drama with looking good Actors and act naturally. The main reason for the Singaporean people, to choose TV dramas was because of the actors and the interesting content.

\section{Indonesians}

Most Indonesians watch Thai television series by watching only the series that is multi-episode series under the same storyline with each episode has a different case but the main character remains the same. And popular television drama series ended. The duration of the broadcast is 30 or 60 minutes. In addition, Indonesian people like to watch foreign television drama, especially Korean television drama. They choose drama because of the interesting story and actor. Most Indonesians watch television drama alongside with the Internet (YouTube).

\section{The Need of Television Drama Plots of Asean People}

The study found that the 'religious plot' was most popular among Myanmar, followed by the Filipinos, and least popular among Lao people. The 'ghost plot' is most popular among Thais, followed by the Vietnamese and least popular among Lao people. The 'teenage plot' is most popular among Thais, followed by the Myanmar and least popular among 
Cambodian. The 'high society plot' is most popular among Thais, followed by Filipinos and least popular among Cambodian. The 'scientific plot' is popular among Thais, followed by the Filipinos and least popular among Cambodians. The 'conflict plot' is most popular among Filipinos, followed by Thai and least popular among Lao people.

\section{The Need of Cultural Contents in the Television Drama of Asean People}

The study indicated that the content of 'Thai beliefs' in television dramas is the most need of the Thai people, followed by Brunei and the least is Laos. The content of 'Thai textiles' is the need of the Thai people, followed by Indonesians and the least preference by Singaporeans. The content of 'Thai folk plant' is the most desirable of Indonesians, followed by Thai people and the least is Myanmar. The content of 'Thai cooking' is the most desirable for the Singaporeans, followed by the Thai and the least desirable is the Lao. The content of Thai dancing is the most desirable of the Thais, followed by Indonesians and the least desirable is the Lao people. The content of 'Thai fortune teller' is the most desirable of the Thais, followed by the Myanmar and the least desirable is the Lao people. The content of 'Thai folklore' is the most desirable of the Thais, followed by the Filipinos and Indonesians, and the least desirable is the Lao people. The content that shows about 'Thai education' is the most desirable of the Thais, followed by Singaporeans and the least desirable is the Lao people. The content of 'Thai marriage' is the most desirable of the Thais, followed by Indonesians and least desirable Cambodians. The content of 'Thai therapy' is the most desirable of the Thais, followed by the Filipinos, and the least desirable is the Lao people.

\section{The Patterns of Exposure to Television Drama of Asean People}

Table 1: Show the Pattern of TV Drama Exposure Behavior of People in Asean Countries

\begin{tabular}{|l|c|c|}
\hline \multirow{2}{*}{ Countries } & \multicolumn{2}{|c|}{ The Exposure to Television Drama } \\
\cline { 2 - 3 } & $\begin{array}{c}\text { Moderate to Very High } \\
\text { Level Directions. }\end{array}$ & $\begin{array}{c}\text { Moderate to Very } \\
\text { Low Level Directions. }\end{array}$ \\
\hline Cambodia & & $\checkmark$ \\
\hline Thailand & $\checkmark$ & \\
\hline Brunei & $\checkmark$ & \\
\hline Philippines & $\checkmark$ & \\
\hline Malaysia & $\checkmark$ & \\
\hline Myanmar & $\checkmark$ & $\checkmark$ \\
\hline Laos & & \\
\hline Vietnam & $\checkmark$ & \\
\hline Singapore & $\checkmark$ & \\
\hline Indonesia & $\checkmark$ & \\
\hline
\end{tabular}

From Table 1, it is found that, the exposure to television drama in ASEAN consists of 2 patterns: 1). The countries where the exposure to television drama is moderate to very high-level directions which include Thailand, Brunei, Philippines, Malaysia, Vietnam, Singapore and Indonesia and 2) the countries where the exposure to television drama is moderate to very low-level directions which include Cambodia and Laos.

The group that has a tendency moderate to very high-level directions is the group that has exposure behaviors that watch at foreign television dramas alongside the Internet, (YouTube) watching foreign television that not shown in the country, watch TV and read the story together, read reviews on the internet, friends, and Teaser-Trailer have to impact on selecting the television series. 
The Patterns of the Need of Television Plots of Asean People

Table 2: Show the Pattern of the Need of Television Plots of Asean People

\begin{tabular}{|l|c|c|c|c|c|c|}
\hline \multirow{2}{*}{ Countries } & \multicolumn{7}{|c|}{ The Need of Television Plots } \\
\cline { 2 - 7 } & Religion & Ghosts & Teenagers & High Society & Science & Conflict \\
\hline Cambodia & $\boldsymbol{x}$ & $\boldsymbol{x}$ & $\boldsymbol{x}$ & $\boldsymbol{x}$ & $\boldsymbol{x}$ & - \\
\hline Thailand & $\checkmark$ & $\checkmark$ & $\checkmark$ & $\checkmark$ & $\checkmark$ & $\checkmark$ \\
\hline Brunei & $\checkmark$ & $\checkmark$ & $\checkmark$ & $\checkmark$ & - & x \\
\hline Philippines & $\checkmark$ & $\checkmark$ & $\checkmark$ & $\checkmark$ & $\checkmark$ & $\checkmark$ \\
\hline Malaysia & $\checkmark$ & $\checkmark$ & $\checkmark$ & $\checkmark$ & $\checkmark$ & $\checkmark$ \\
\hline Myanmar & $\checkmark$ & $\checkmark$ & $\checkmark$ & $\checkmark$ & - & x \\
\hline Laos & $\boldsymbol{x}$ & $\boldsymbol{x}$ & $\checkmark$ & $\checkmark$ & $\checkmark$ & x \\
\hline Vietnam & $\checkmark$ & $\checkmark$ & $\checkmark$ & $\checkmark$ & $\checkmark$ & $\checkmark$ \\
\hline Singapore & $\checkmark$ & - & $\checkmark$ & $\checkmark$ & - & $\checkmark$ \\
\hline Indonesia & $\checkmark$ & $\checkmark$ & $\checkmark$ & $\checkmark$ & $\checkmark$ & $\checkmark$ \\
\hline
\end{tabular}

From Table 2, it was found that the pattern of exposure of plots of TV drama among people in ASEAN countries can be seen in 2 patterns: 1) countries with various plot exposure

2) Countries that have exposure to plots in a particular manner.

Groups that are exposed to plots are characterized by a various plot exposure group, plots of every subject, or almost every subject that is offered such as Thailand, the Philippines, Malaysia, Vietnam, and Indonesia. The group that is exposed to specific plots is exposed to certain television drama plots only such as Cambodia, Brunei, Myanmar, Laos, and Singapore.

The Patterns of the Need of Cultural Contents in the Television

Drama of Asean People

Table 3:.Show The Pattern of the Need of Cultural Contents in the Television Drama of Asean People

\begin{tabular}{|c|c|c|c|c|c|c|c|c|c|c|}
\hline \multirow{2}{*}{ Countries } & \multicolumn{10}{|c|}{$\begin{array}{l}\text { The Need of Cultural Contents in the Television Drama } \\
\text { of ASEAN People }\end{array}$} \\
\hline & 1 & 2 & 3 & 4 & 5 & 6 & 7 & 8 & 9 & 10 \\
\hline Cambodia & $x$ & $x$ & $x$ & $\checkmark$ & $x$ & $x$ & $x$ & $x$ & $x$ & $x$ \\
\hline Thailand & $\checkmark$ & $\checkmark$ & $\checkmark$ & $\checkmark$ & $\checkmark$ & $\checkmark$ & $\checkmark$ & $\checkmark$ & $\checkmark$ & $\checkmark$ \\
\hline Brunei & $\checkmark$ & $\checkmark$ & $\checkmark$ & $\checkmark$ & $\checkmark$ & - & - & - & $\checkmark$ & - \\
\hline Philippines & $\checkmark$ & $\checkmark$ & $\checkmark$ & $\checkmark$ & $\sqrt{ }$ & $\checkmark$ & $\checkmark$ & $\checkmark$ & $\checkmark$ & $\checkmark$ \\
\hline Malaysia & $x$ & $\checkmark$ & $\checkmark$ & $\checkmark$ & $\sqrt{ }$ & $\checkmark$ & $\sqrt{ }$ & $\checkmark$ & $\sqrt{ }$ & $\checkmark$ \\
\hline Myanmar & $\checkmark$ & $x$ & $x$ & $\checkmark$ & $\checkmark$ & $\checkmark$ & - & $\checkmark$ & $\checkmark$ & $\checkmark$ \\
\hline Laos & $x$ & $x$ & - & $x$ & $x$ & $x$ & $x$ & - & $x$ & $x$ \\
\hline Vietnam & $\checkmark$ & $\checkmark$ & $\checkmark$ & $\checkmark$ & $\sqrt{ }$ & $\checkmark$ & $\sqrt{ }$ & $\checkmark$ & $\sqrt{ }$ & $\checkmark$ \\
\hline Singapore & - & - & - & $\checkmark$ & $\checkmark$ & - & $\checkmark$ & $\checkmark$ & $\checkmark$ & $\checkmark$ \\
\hline Indonesia & - & $\checkmark$ & $\checkmark$ & $\checkmark$ & - & $\checkmark$ & - & $\checkmark$ & $\checkmark$ & $\checkmark$ \\
\hline
\end{tabular}

Note: 1 . Thai beliefs 2 . Thai textiles 3 . Thai native plants 4 . Thai cooking 5 . Thai dancing 6 . Thai fortune tellers

7. Thai folklore 8 . Thai education 9 . Thai marriage 10. Thai therapy

From Table 3, it was found that the pattern of the need of cultural contents in the television drama of ASEAN people can be seen in 2 patterns: 1) the need of cultural contents in the television drama of ASEAN in a variety of ways such as Thailand, Brunei, Philippines, Vietnam, and Indonesia. 2). the need of cultural contents in the television drama of ASEAN in a particular way such as Cambodia, Malaysia, Myanmar, Laos, and Singapore. 


\section{DISCUSSIONS}

The results of the exposure to television drama revealed that almost every country chooses to watch TV according to their personal preference. This may be because the television series has a plot and a variety of content. So, most of the people choose to watch only their favorite program. Becker (1972) explain that people will be exposed to information that is relevant to their interests and that if they have information related to themselves, they will give special attention to read or to watch or listen to those concepts that can support the findings that most people are expose to their favorite TV series. However the study indicated that Singaporeans have been exposed to television dramas occasional ones. This may explain that there are not many varieties to watch in Singapore where most people like watching movies rather than TV series because they spend less time. (Aven Lai, 2017).

The study also found that, television drama under the same storyline is popular in many ASEAN countries. This corresponds to the findings of Samuel, et.al. (2007) the series is a continuation of the story that can stimulate to familiarize and fascinate with the drama than the short story. The popularity of drama in a different way, can be used as a guideline to design dramatic style to suit the preferences of the audience. It will better make the substance reach the audience. This is consistent with the statement

Burger (2012) says that the preparation of the substance to the recipient will result in more exposure than the substance that does not correspond to the recipient. Also, Klapper (1960: 56) gives similar views that the person will be exposed to the content that corresponds to their needs. Those content will create awareness and recognition that affect the behavior of the person at a later time which includes marketing behavior (Joanne, Toddlers 2005 and C. J. Y and Y. S. Shuo 2011).As can be seen, the influence of Korean dramas can have a positive impact on Korean tourism. (Hoa et.al (2015) Samuel, et.al. (2007) and Jerome, et.al (2008)) that means if the Thai cultural content is presented in a television drama that can raise awareness in ASEAN countries. It will result in exposure and affect other behaviors, such as the need to travel in Thailand or the desire to buy Thai products as presented in the television series.

Normally, ASEAN countries are grouped by religion, such as countries, religions, Buddhas, Thailand, Laos, Cambodia and Myanmar. Islamic countries include Malaysia, Indonesia and Brunei. The countries of different religions are Vietnam and Singapore. Christianity is only the Philippines. Also, it can be grouped by geographic features: Thailand, Cambodia, Vietnam, Myanmar and Brunei. It consists of Singapore, Malaysia, Indonesia and the Philippines. (aseaninfo.com 2560)In this study, the research found that the concept of ASEAN countries consists of 3 groups. Group 1 consists of Thailand, Laos and Cambodia. Group 2 consists of Malaysia. Singapore and Vietnam, and Group 3 include Indonesia and the Philippines.

The results show that the three groups are a mixture of religion and geographic features. The concept is that the patterns of grouping countries depend on the variables that they want to group and the purpose of utilization. This study uses the composition of the television drama exposure, plots exposure and cultural content requirements as segmentation.

\section{RECOMMENDATIONS}

Creating awareness on TV drama for Brunei, Philippines, Malaysia, Myanmar, Vietnam, Singapore and Indonesia must be done through traditional Media coupled with new media. The perception process can be done through an agency to bring the drama to theaters, and to market in the traditional way, such as advertising through media, television, billboards, or print media. The perception process can be accomplished through the agency for the official import television drama, as 
well as creating awareness through traditional media such as advertising through media, television, billboards, or print media, along with the new media by creating an online presence, such as presenting an interview drama directors, celebrities, dramatic reviews, present a visual of the drama, as well as participate in the prize to stimulate exposure.

The content for the Teaser-Trailer should be focusing on some scenes that can inspire interest. Also, television drama content should be short but must be easy to understand. There is a beautiful environment with fine productions in English language. Cambodia and Laos should focus on communicating through traditional media in an informal manner. Include localized presentations that most people understand. Perception creation can be accomplished by organizing a talk event with the actor in the story. Perception creation can be accomplished by organizing a talk event with the actor in the story. Organize activities to meet fans in Cambodia and Laos. It is important to create a drama by international cooperation by bringing the famous actor of that country to the event.

The results indicate that the plot and cultural content was chosen to suit the target countries. Especially in Cambodia and Laos, attention is paid to the presentation of television dramas due to the limited exposure of the population.

\section{REFERENCE}

1. Alberti. F.G., and Giusti. J., (2012) Cultural heritage, tourism and regional competitiveness: The Motor valley cluster. City, Culture and Society2: pp.261-273.asean-info.com available at http://www.asean-info.com retrieved at February 8, 2560

2. Becker. S. L., (1972). Discovering Mass Communication. Illinois: Scott Foresman and Company Glenview.

3. C. J. Y., and Y. S. Shuo., (2011). The examination of factors influencing resident's perceptions and attitudes toward film induced tourism, African Journal of Business Management. 5(13), pp. 5371-5377.

4. Cooke. P., and Lazzeretti. L., (2008).Creative Cities, Cultural Clusters and Local Economic Development. Cheltenham: Edward Elgar.

5. Hoa. NN, Kobayashi. J, Omura. M, Hirakawa. M, Yang. S-H, Komatsu. K, et al., (2015).BRCAl and CtIP Are Both Required to Recruit Dna2 at Double-Strand Breaks in Homologous Recombination. PLoS ONE 10(4): e0124495.

6. Jay-Ar M. Igno and Marie Cielo E. Cenidoza., (2016). Beyond the "Fad": Understanding Hallyu in the Philippines. International Journal of Social Science and Humanity, 6(9). 723-727.

7. Joanne,- Toddlers C.,(2005). Tourism and Tobermory: Destination marketing issues and television-induced tourism, Tourism Management, 26,pp. 763-776.

8. Klapper, J. T., (1960). The Effects of Mass Communication. Glencoe, IL: Free Press. Lazzeretti. L., Capone F, and Cinti T (2011). Open innovation in city of art: The case of laser technologies for conservation in Florence. City, Culture and Society2: 159-168.

9. Power. D., and Scott. A., (eds.) (2004).Cultural industries and the production of culture. London: Routledge

10. Rabaneda. R.A., (2012). Cultural events and cultural heritage in times of crisis: A case in Catalonia. In: Lyck L, Long P, and Grige AX (eds.) Tourism, festivals and cultural events in times of crisis. Vanløse: Frederiksberg Bogtrykkeri, 25-36.

11. Samuel. K. S., Jerome.A., L. Heesung, and C. Kaye, (2007). "Effects of Korean television dramas on the flow of Japanese tourists, "Tourism Management, 28(5), pp. 1340-1353,

12. Smith. M.K., (2009).Issues in cultural tourism studies. London: Routledge. Interview Aven Lai, on July 8, 2017. 